\title{
42. Ortaöğretim T.C. İnkılâp Tarihi ve Atatürkçülük dersi kazanımlarının elde edilmesinde şiirlerin etkisine ilişkin öğrenci görüşleri ${ }^{1}$
}

Sezai ÖZTAŞ²

Bülent KILIÇ3

\begin{abstract}
APA: Öztaş, S.; Kılıç, B. (2021). Ortaöğretim T.C. İnkılâp Tarihi ve Atatürkçülük dersi kazanımlarının elde edilmesinde şiirlerin etkisine ilişkin öğrenci görüşleri. RumeliDE Dil ve Edebiyat Araştırmalar Dergisi, (24), 735-745. DOI: 10.29000/rumelide.997697.
\end{abstract}

\section{$\ddot{\mathbf{O} z}$}

Tarih derslerinde kazanımların elde edilmesinde kullanılabilecek materyallerden biri de şiirlerdir. Şiirlerde yazıldıkları dönemin tarihsel olaylarını, toplumun sosyal, kültürel, ekonomik yapısını, halkın acılarını ve sevinçlerini, toplumun değer yargılarını bulabilmek mümkündür. Bu bakımdan tarih derslerinde kazanımların elde edilmesinde şiirlerin kullanılması önem taşımaktadır. Bu çalışmanın amacı, ortaöğretim T.C. İnkılâp Tarihi ve Atatürkçülük dersi kazanımlarının elde edilmesinde şiirlerin etkisine ilişkin öğrenci görüşlerini tespit etmektir. Araştırmada veri toplama aracı olarak kullanılan anketler, 2017-2018 eğitim-öğretim yılı ikinci döneminde Kırklareli ilinde Kırklareli Fen Lisesi'nde öğrenime devam eden ve T.C. İnkılâp Tarihi ve Atatürkçülük dersini alan öğrencilerden toplam 81 öğrenciye uygulanmıştır. Toplanan verilerin analizi için IBM SPSS Statistics 20 programından yararlanılmıştır. Toplanan verilere ait tanımlayıcı istatistikler ayrıntılı olarak verilmiştir. Yapılan bağımsız örneklem t-testi ve varyans analizleri sonucunda "cinsiyet"e, "tarih ile ilgili derslere olan ilgi”ye, "şiir okuma" durumuna ve "şiir okumayı sevme" durumlarına göre öğrencilerin ortaöğretim T.C. İnkılâp Tarihi ve Atatürkçülük dersi kazanımlarının elde edilmesinde şiirlerin etkisine ilişkin tutum düzeylerinin istatistiksel olarak anlamlı bir farka rastlanmamıştır.

Anahtar kelimeler: Tarih, T.C. İnkılâp Tarihi ve Atatürkçülük dersi, şiir, öğrenci görüşleri

\section{Students' opinions on the effect of poems in achieving the learning outcomes of secondary education Turkish Republic History of the Revolution and Ataturkism Course}

\author{
Abstract \\ One of the materials that can be used to achieve the learning outcomes of history courses is poetry. It \\ is possible to find the historical events of the period, the social, cultural and economic structure of \\ the society, the sorrows and joys of the community and the value judgments of the society in the \\ poems. In this respect, it is important to use poems in achieving the learning outcomes of history \\ courses. The aim of this study is to find out what students' opinions on the effect of poems in achieving \\ the learning outcomes of Secondary Education Turkish Rebuplic History of the Revolution and \\ Ataturkism Course are. The questionnaires used as a data collection tool in the survey were applied \\ Bu çalışma, 10-12 Mayıs 2018 tarihinde düzenlenen V. Uluslararası Tarih Eğitimi Sempozyumu'nda sunulmuş sözlü \\ bildirinin geliştirilerek yeniden düzenlenmiş halidir. \\ Doç. Dr., Tekirdağ Namık Kemal Üniversitesi, Fen Edebiyat Fakültesi, Tarih Bölümü (Tekirdağ, Türkiye), \\ sezaioztaş@hotmail.com, ORCID ID: oooo-0002-1742-4200 [Araştırma makalesi, Makale kayıt tarihi: 13.08.2021-kabul \\ tarihi: 20.09.2021; DOI: 10.29000/rumelide.997697] \\ 3 Öğr. Gör., Kırklareli Üniversitesi, Lüleburgaz Meslek Yüksekokulu, Bilgisayar Teknolojileri Bölümü (Kırklareli, Türkiye), \\ rbulentkilic@gmail.com, ORCID ID: 00o0-0002-1554-1761 \\ Adres $\mid$ Address \\ RumeliDE Dil ve Edebiyat Araştırmaları Dergisi \\ Osmanağa Mahallesi, Mürver Ciçeği Sokak, No:14/8 \\ Kadıköy - İSTANBUL / TÜRKIYE 34714 \\ e-posta: editor@rumelide.com \\ RumeliDE Journal of Language and Literature Studies \\ Osmanağa Mahallesi, Mürver Çiçeği Sokak, No:14/8 \\ Kadıköy - ISTANBUL / TURKEY 34714 \\ e-mail: editor@rumelide.com, \\ tel: +90 505 7958124, +90 2167730616 phone: +90 505 7958124, +90 2167730616
}


to a total of 81 students who were enrolled in the second semester of 2017-2018 academic year at Kurklareli Science High School in Kırklareli City and who took Turkish Republic History of Revolution and Ataturkism course. IBM SPSS Statistics 20 program was used to analyze the collected data. Descriptive statistics of the collected data were given in detail. Also, independent sample t-test and One-Way ANOVA were performed, and it was found that there is no statistically significant difference in attitude levels of the students regarding their opinions on the effect of poems in achieving the learning outcomes of Turkish Republic History of Revolution and Ataturkism course based on "gender", "interest in courses related to history", "frequency of reading poems" and "liking to read poems" $(\mathrm{p}<0,05)$.

Keywords: History, Turkish Republic History of Revolution and Ataturkism course, poetry, students' opinions

\section{Giriş}

Türkiye'de 2004 yılından itibaren uygulanmaya başlanılan yapılandırmacı (oluşturmacı) yaklaşım ilkelerine uygun olarak öğretim programlarında öğretim materyallerinin kullanımı daha da önem kazanmıştır. Çünkü yapılandırmacı (oluşturmacı) yaklaşım çerçevesinde öğrencilere kazandırılması istenilen, bilgi, beceri, değer ve kavramların anlatım yönteminin dışında özellikle materyaller kullanılarak daha kalıı hale getirilmesi amaçlanmaktadır (Ulusoy ve Gülüm, 2009: 86).

İlgili bilgi, beceri, değer ve kavramların kazandırılmasında kullanılabilecek materyallerden biri de şiirlerdir. Şiir, "dilin anlam, ses ve ritim ögelerini belli bir düzen içinde kullanarak, bir olayı ya da bir duygusal ve düşünsel deneyimi yoğunlaşmış, sıradanlıktan uzaklaşmış bir biçimde anlatma sanatıdır." (Öztürk ve Otluoğlu, 2005: 119). Şiirlerde yazıldıkları dönemin tarihsel olaylarını, toplumun sosyal, kültürel, ekonomik yapısını, halkın acılarını ve sevinçlerini, toplumun değer yargılarını bulabilmek mümkündür. Bu bakımdan tarih derslerinde kazanımların elde edilmesinde şiirlerin kullanılması önem taşımaktadır.

Ortaöğretim T.C. İnkılâp Tarihi ve Atatürkçülük Dersi Öğretim Programı'nın uygulanmasında dikkat edilecekler kısmında "ders kitabında geçmişe dair belgelerin yanı sıra resim, şiir, roman, biyografi, hikâye ve özlü sözlere yer verilmesi" (MEB, 2018) istenilmektedir.

Şiir, tarihsel olayların ruhunu ifade eder ve insan bakış açısını sağlar. Ayrıca şiir, sınıftaki öğretmenler için erişilebilirlik, çeşitlilik ve anlama bakımından yararlıdır. Bu üç özellik şiirin öğrencilerin ilgisini çekmesini, grup içinde bireysel ihtiyaçlarını karşılamasını ve anlamalarında yardımcı olduğunu ortaya koymaktadır (Collins, 2008).

Şiirler, tarih derslerinde öğretmenin üstlenmiş olduğu anlatıcılık görevini desteklemekte, ders kitaplarındaki ana metni zenginleştirmekte, ders kitabından kaynaklanan sıkıcılık, anlaşılmazlık gibi problemlerin çözülmesinde yardımcı olmakta, eleştirel okuma, karşılaştırma yapma ve metinler arası okuma gibi becerileri kazandırabilmektedir (Köksal, 2010: 253-256).

Çencen'e (2010: 124) göre şiirler şu sebeplerle T.C. İnkılâp Tarihi ve Atatürkçülük dersi kazanımlarının elde edilmesinde işlevsel bir öğretim materyali olarak görülebilir:

- Tarihin ilk zamanlarından başlayarak insanın yaşadıklarını, düşündüklerini, hissettiklerini ve istediklerini bir sonraki nesile aktaran güvenilir ve en kolay bilgi taşıma aracı olması,

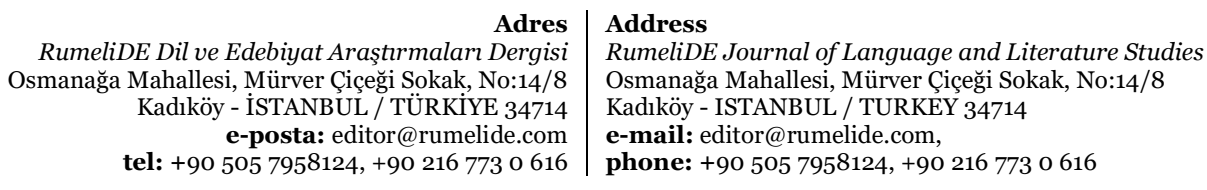


- Dile özel bir ritim ve ahenk katarak onu hatıralar biçiminde bireyin hafizasına yerleștirmesi,

- Birikimli bilgiyi bir çeşit keyifli oyuna dönüştürerek öğrenmeyi gerçekleştirmesi,

- İnsana heyecan verici yoğun duygular yaşattrken diğer yandan da onu düşünmeye sevk etmesi,

- $\quad$ Nesnelerin ve olaylarn sadece dış görünüşlerine göre değil aynı zamanda farkh bakış açları ile düşünülerek değerlendirilme sağlaması,

- Tarihsel olgu ve kavramları öğretmeyi kolaylaştırması,

- Dersi tekdüzelikten kurtarması, öğrenci katılımını artırması,

- Öz güven kazandırması, yaratıcılı̆̆ geliştirmesi ve motive edici olması,

- Her öğrenci farkh anlamlar çıaracağı için her bireyin farkh düşünce yapılarına sahip olduğu gerçeğini öğretmesi,

- Öğrencilerde estetik kavramı hem düşünsel hem de biçimsel olarak geliştirmesi,

- Öğrenme psikolojisinin inceleme alanına giren "learning by doing" ilkesi ile öğrencilere yaparak-yaşayarak öğrenmeyi öğretmesi”.

İlgili alan yazın incelendiğinde şiirlerin eğitimde kullanılması üzerine yapılmış çalışmaların (Collins, 2008; Certo, 2004; Dunning, 1966; Janeczko, 2003; Kirman, 2007; Liftig, 1993; Stiles, 1965; Vardell, 2006; Walders, 2000) yanında şiirlerin tarih eğitiminde kullanılması gerektiğini vurgulayan (Candan, 2003; Çencen, 2010; Çencen ve Akça Berk, 2014; Harrison ve Holderith, 2003; Kenworthy, 1937; Köksal, 2010; McCall, 2004; Osborne, 1987; Öztaş, 2009; Öztaş, 2018; Wilson ve Kahn, 2008) çalışmalar da mevcuttur.

Bu çalışmanın amacı, ortaöğretim T.C. İnkılâp Tarihi ve Atatürkçülük dersi kazanımlarının elde edilmesinde şiirlerin etkisine ilişkin öğrenci görüşlerini tespit etmektir. Çalışmanın amacı doğrultusunda aşağıda belirtilen araştırma sorularına cevap aranmaktadır:

1. Öğrencilerin, ortaöğretim T.C. İnkılâp Tarihi ve Atatürkçülük dersi kazanımlarının elde edilmesinde şiirlerin etkisine ilişkin tutum (KŞET) düzeyleri nelerdir?

2. Öğrencilerin KŞET düzeylerinde cinsiyetlerine göre istatistiksel olarak anlamlı bir fark var mıdır?

3. Öğrencilerin tarih ile ilgili derslere olan ilgi durumlarına göre KŞET düzeylerinde istatistiksel olarak anlamlı bir fark var mıdır?

4. Öğrencilerin şiir okumayı sevme durumlarına göre KŞET düzeylerinde istatistiksel olarak anlamlı bir fark var midır?

5. Öğrencilerin şiir okuma durumlarına göre KŞET düzeylerinde istatistiksel olarak anlamlı bir fark var midır?

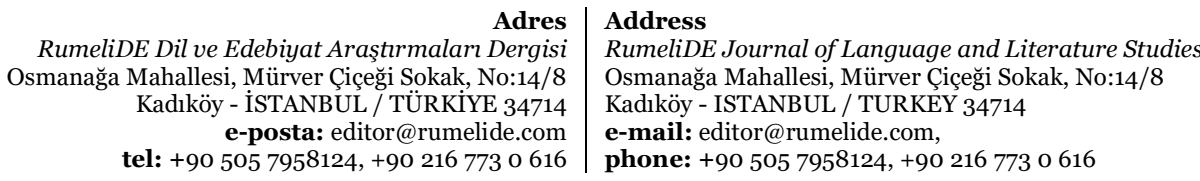




\section{Yöntem}

\subsection{Araşturma modeli}

$\mathrm{Bu}$ araştırmada tarama modeli kullanılmıştır. Tarama modelleri, geçmişte ya da halen var olan bir durumu var olduğu şekliyle betimlemeyi amaçlayan araştırma yaklaşımlarıdır (Karasar, 2012). Büyüköztürk ve diğerleri (2010) ise tarama modelini araştırmanın amacına uygunluğu, var olan durumu ortaya koyması, büyük örneklemler üzerinde çalışma olanağı sunması, bir konuya ya da olaya ilişkin katılımcıların görüşleriyle ilgili fikirler vermesi gibi özellikleri sebebiyle kullanılan bir araştırma türü olarak tanımlamaktadır.

\subsection{Evren ve örneklem}

Araştırma evrenini, 2017-2018 eğitim-öğretim yllı ikinci döneminde Kırklareli ilinde öğrenimlerine devam eden ve ortaöğretim T.C. İnkılâp Tarihi ve Atatürkçülük dersini alan öğrenciler oluşturmaktadır. Araştırmada örnekleme yöntemi olarak küme örneklemesi tercih edilmiştir. Buna göre 2017-2018 eğitim-öğretim yılı ikinci döneminde Kırklareli ilindeki Kırklareli Fen Lisesi'nde öğrenime devam eden ve öğretim T.C. İnkılâp Tarihi ve Atatürkçülük dersini alan öğrencilerden toplam 81 öğrenci örnekleme alınmıştır.

\subsection{Veri toplama aracı}

Araştırmada veri toplama aracı olarak kullanılan anket, araştırmacılar tarafından geliştirilmiştir. T.C. İnkılâp Tarihi ve Atatürkçülük Dersi Öğretim Programı (2018)'nda yer alan tüm kazanımlar (33 adet) kullanılarak, T.C. İnkılâp Tarihi ve Atatürkçülük dersi kazanımlarının elde edilmesinde şiirlerin etkisine ilişkin tutum düzeyleri belirlenmesinde kullanılan ifadeler oluşturulmuştur. Bu ifadelerin herbiri için ankete katılan öğrencilerin “(1) Hiç Katılmıyorum”, “(2) Katılmıyorum”, “(3) Ne Katılıyorum, Ne Katılmıyorum”, “(4) Katıllyorum” ve “(5) Tamamen Katılıyorum” şeklinde derecelendirilmiş seçeneklerden birini işaretlemeleri istenmiştir. Herbir öğrencinin bu 33 adet ifadeye verdiği tepkilerin puan toplamı alınarak bu öğrencilerin her birine ait KŞET düzeyleri hesaplanmıştır. Bu sebeple, bu kısımdan alınabilecek en yüksek KŞET düzeyi 165 puan, en düşük KŞET düzeyi ise 33 puandır. Burada alınan yüksek puanlar, T.C. İnkılâp Tarihi ve Atatürkçülük dersi kazanımlarının elde edilmesinde şiirlerin etkisine ilişkin olumlu tutumu göstermektedir.

\subsection{Verilerin analizi}

Toplanan verilerin analizi için IBM SPSS Statistics 20 programından yararlanılmıştır. Anketteki "cinsiyet", "tarih ile ilgili derslere olan ilgi", "şiir okumayı sevme durumları" ve "şiir okuma durumları" na ait verilerin analizi için frekans analizinden yararlanılmıştır. Buna ek olarak öğrencilerin, T.C. İnkılâp Tarihi ve Atatürkçülük dersi kazanımlarının elde edilmesinde şiirlerin etkisine ilişkin tutum düzeylerinin araştırıldığı 33 adet maddenin herbirine ait ortalama ve standart sapma değerleri tablo ile özetlenmiştir. Öğrencilerin KŞET düzeylerinde cinsiyetlerine göre istatistiksel olarak anlamlı bir fark olup olmadığının analizinde bağımsız örneklem t-testinden yararlanılmıştır. Öğrencilerin KŞET düzeylerinde "tarih ile ilgili derslere olan ilgi", "şiir okumayı sevme" ve "şiir okuma" durumlarının herbirine göre istatistiksel olarak anlamlı bir fark olup olmadığının analizinde varyans analizinden yararlanılmıştır. Yapılan bu bağımsız örneklem t-testi ve varyans analizlerinin sonuçları \% 5 anlam düzeyi esas alınarak yorumlanmıştır.

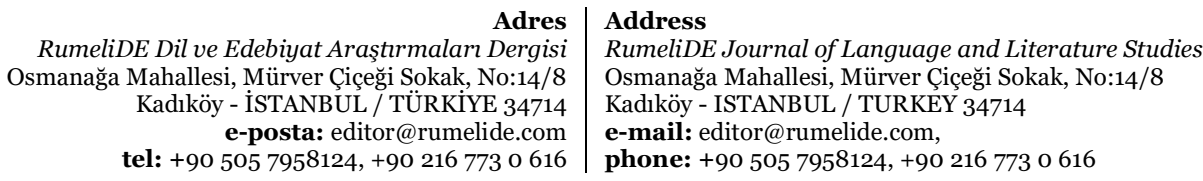




\section{Bulgular}

\section{Tanmmlayıce istatistikler}

Bu bölümde araştırmadan elde edilen bulgulara yer verilmiştir.

Tablo 1. Öğrencilerin Cinsiyetlerine Göre Dağılımları

\begin{tabular}{lll}
\hline & Frekans & Oran (\%) \\
\hline Kiz & 46 & 56,8 \\
Erkek & 35 & 43,2 \\
TOPLAM & 81 & 100 \\
\hline
\end{tabular}

Buna göre; öğrencilerin \% 56,8’i kız , \% 43,2’si erkektir (Tablo 1).

Tablo 2. Öğrencilerin tarih ile ilgili derslere olan ilgi düzeylerine ilişkin dağılımları

\begin{tabular}{lll}
\hline & Frekans & Oran (\%) \\
\hline Çok Zayıf & 3 & 3,7 \\
Zayıf & 8 & 9,9 \\
Orta & 37 & 45,7 \\
Yüksek & 27 & 33,3 \\
Çok Yüksek & 6 & 7,4 \\
TOPLAM & & \\
\hline
\end{tabular}

Buna göre; tarih ile ilgili derslere olan ilgi düzeyi olarak öğrencilerin \% 3,7'si "Çok Zaylf", \%9,9'u "Zayıf", \% 45,7'si "Orta", \%33,3'ü "Yüksek" ve \%7,4'ü "Çok Yüksek " cevabını vermişlerdir (Tablo 2).

Tablo 3. Öğrencilerin şiir okumayı sevme durumlarına ait dağılımları

\begin{tabular}{lll}
\hline & Frekans & Oran (\%) \\
\hline Evet & 24 & 29,6 \\
Hayir & 21 & 25,9 \\
Kismen & 36 & 44,4 \\
TOPLAM & 81 & 100,0 \\
\hline
\end{tabular}

Buna göre; şiir okumayı sevme durumu olarak öğrencilerin \% 29,6' sı şiir okumayı sevdiklerini, \%25,9'u sevmediklerini ve \%44,4'ü kısmen sevdiklerini belirtmişlerdir (Tablo 3).

Tablo 4. Öğrencilerin Şiir Okuma Durumlarına Ait Dağılımları

\begin{tabular}{lll}
\hline & Frekans & Oran (\%) \\
\hline Hiçbir zaman & 13 & 16,7 \\
Nadiren & 33 & 40,7 \\
Bazen & 23 & 28,4 \\
Stk sık & 12 & 16,0 \\
TOPLAM & 81 & 100,0 \\
\hline
\end{tabular}


Buna göre; şiir okuma durumu olarak öğrencilerin \% 16 sı "Hiçbir Zaman", \%40,7'si "Nadiren", \%28,4'ü

"Bazen" ve \%16'sı "Sık Sık" cevabını vermişlerdir (Tablo 4).

1. Öğrencilerin, ortaöğretim T.C.İnkllâp Tarihi ve Atatürkçülük dersi kazanımlarının elde edilmesinde şïrlerin etkisine ilişkin tutum (KŞET) düzeyleri nelerdir?

Tablo 5. Kazanımlarının elde edilmesinde şiirlerin etkisine ilişkin tutum düzeyleri ortalamaları ve standart sapmaları

\begin{tabular}{|c|c|c|}
\hline Kazanımlarının elde edilmesinde şiirlerin etkisine ilişkin ifadeler & Ortalama & $\begin{array}{l}\text { Standart } \\
\text { Sapma }\end{array}$ \\
\hline $\begin{array}{l}\text { Ko1: Şïrler; Mustafa Kemal'in Birinci Dünya Savaşı'na kadarki eğitim ve askerlik } \\
\text { hayatını, içinde bulunduğu toplumun siyasi, sosyal ve kültürel yapısı ile } \\
\text { ilişkilendirmemde faydalıdırlar. }\end{array}$ & 3,57 & 0,999 \\
\hline $\begin{array}{l}\text { Ko2: Şiirler; 20. yüzyıl başlarında Osmanlı Devleti'nin siyasi, sosyal ve ekonomik } \\
\text { durumunu analiz etmemde faydalıdırlar. }\end{array}$ & 3,38 & 1,044 \\
\hline $\begin{array}{l}\text { Ko3: Şiirler; I. Dünya Savaşı sürecinde Osmanlı Devleti’nin durumunu siyasi, askerî } \\
\text { ve sosyal açılardan analiz etmemde faydalıdırlar }\end{array}$ & 3,4 & 1,057 \\
\hline $\begin{array}{l}\text { Ko4: Şiirler; I. Dünya Savaşı'nın sonuçlarını Osmanlı Devleti ve Batılı devletler } \\
\text { açısından değerlendirmemde faydalıdırlar. }\end{array}$ & 3,32 & 0,946 \\
\hline $\begin{array}{l}\text { Ko5: Şiirler; Kuvay-ı Millîye hareketinin oluşumundan Büyük Millet Meclisinin } \\
\text { açılışına kadar olan süreçte meydana gelen gelişmeleri açılamamda faydalıdırlar. }\end{array}$ & 3,42 & 1,071 \\
\hline $\begin{array}{l}\text { Ko6: Şiirler; Büyük Millet Meclisinin açılış sürecini ve sonrasında meydana gelen } \\
\text { gelişmeleri kavramamda faydalıdırlar. }\end{array}$ & 3,31 & 1,158 \\
\hline
\end{tabular}

Ko7: Şiirler; Sevr Antlaşması'nın Millî Mücadele sürecine etkilerini analiz etmemde

faydalıdırlar.

$3,26 \quad 1,104$

Ko8: Şiirler; Doğu ve Güney Cephelerinde verilen mücadelelerin ülkemizin

bağımsızlık sürecine katkılarını kavramamda faydalıdırlar.

$3,58 \quad 0,986$

Ko9: Şiirler; düzenli ordunun kurulmasından Mudanya Ateşkes Antlaşması'na

kadar meydana gelen gelişmeleri Türkiye'nin bağımsızlık sürecine katkıları

açısından analiz etmemde faydalıdırlar.

$\quad 0,966$

K10: Şiirler; Millî Mücadele sonucunda kazanılan diplomatik başarıları ülkemizin

bağımsızlığı açısından değerlendirmemde faydalıdırlar.

$3,44 \quad 1,049$

K11: Şiirler; Millî Mücadele sürecine katkıda bulunmuş önemli şahsiyetlerin kişilik

özellikleri ile faaliyetlerini ilişkilendirmemde faydalıdırlar.

$3,67 \quad 0,922$

K12: Şiirler; çağdaşlaşan Türkiye’nin temeli olan Atatürk ilkelerini kavramamda faydalıdırlar.

K13: Şiirler; siyasi alanda meydana gelen gelişmeleri kavramamda faydalıdırlar.

K14: Şiirler; hukuk alanında meydana gelen gelişmelerin Türk toplumunda meydana getirdiği değişimleri kavramamda faydalıdırlar.

K15: Şiirler; eğitim ve kültür alanında yapılan inkılapları ve gelişmeleri

kavramamda faydalıdırlar.

K16: Şiirler; toplumsal alanda yapılan inkılapları ve meydana gelen gelişmeleri

kavramamda faydalıdırlar.

$3,3 \quad 0,928$

K17: Şiirler; ekonomi alanında meydana gelen gelişmeleri kavramamda

faydalıdırlar.

$2,99 \quad 1,066$

K18: Şiirler; Atatürk Dönemi’nde sağlık alanında yapılan çalışmaları kavramamda faydalıdırlar.

K19: Şiirler; Atatürk ilke ve inkılaplarını oluşturan temel esasları Atatürkçü düşünce sistemi açısından analiz etmemde faydalıdırlar.

3,7 1,03

\section{Adres | Address}

RumeliDE Dil ve Edebiyat Araştırmaları Dergisi Osmanağa Mahallesi, Mürver Ciçeği Sokak, No:14/8 Kadıköy - İSTANBUL / TÜRKIYE 34714 e-posta: editor@rumelide.com 
K20: Şiirler; Atatürk Dönemi’nde Türkiye Cumhuriyeti’nin iç politikasındaki önemli

gelişmeleri açıllamamda faydalıdırlar.

$\quad 0,996$

K21: Şiirler; Atatürk Dönemi’nde (1923-1938) Türkiye Cumhuriyeti’nin dış

politikasındaki başlıca gelişmeleri açıklamamda faydalıdırlar.

$3,21 \quad 1,009$

K22: Şiirler; iki dünya savaşı arasındaki dönemde dünyada meydana gelen siyasi ve

ekonomik gelişmeleri kavramamda faydalıdırlar.

3,22

0,987

K23: Şiirler; II. Dünya Savaşı'nın sebepleri, başlaması ve yayılmasıyla ilgili başlıca gelişmeleri kavramamda faydalıdırlar.

$\quad 0,975$

K24: Şiirler; II. Dünya Savaşı sürecinde Türkiye'nin izlediği siyaset ile savaşın

Türkiye üzerindeki ekonomik ve toplumsal etkilerini analiz etmemde faydalıdırlar.

K25: Şiirler; II. Dünya Savaşı'nın sonuçlarını değerlendirmemde faydalıdırlar.

K26: Şiirler; 1945-1950 yılları arasında Türkiye'de meydana gelen siyasi, sosyal ve ekonomik gelişmeleri kavramamda faydalıdırlar.

$3,26 \quad 1,046$

K27: Şiirler; II. Dünya Savaşı sonrası dönemde uluslararası ilişkilerde ve Türk dış politikasında meydana gelen gelişmeleri kavramamda faydalıdırlar.

$3,19 \quad 1,014$

K28: Şiirler; 1950'ler Türkiye'sinde meydana gelen siyasi, sosyal ve ekonomik gelişmeleri analiz etmemde faydalıdırlar.

0,907

K29: Şiirler; 1960 sonrasında dünya siyasetinde ortaya çıkan gelişmeleri açıllamamda faydalıdırlar.

$3,1 \quad 0,889$

K30: Şiirler; 1960'lardan itibaren Türk dış politikasını etkileyen önemli gelişmeleri kavramamda faydalıdırlar.

$\quad 0,873$

K31: Şiirler; 1960'lardan itibaren Türkiye'de meydana gelen siyasi, ekonomik ve sosyo-kültürel gelişmeleri analiz etmemde faydalıdırlar.

3,37

0,941

K32: Şiirler; 1990 sonrasında Türkiye'de meydana gelen ekonomik, siyasi, sosyal ve kültürel gelişmeleri kavramamda faydalıdırlar.

3,22

0,975

K33: Şiirler; 1990 sonrasında meydana gelen siyasi gelişmeleri Türkiye'ye etkileri ve dünya siyasi konjonktürü bağlamında analiz etmemde faydalıdırlar.

GENEL TUTUM DÜZEYI (KŞET)*

$3,17 \quad 1,046$

*Alınabilecek yüksek puan 165 puan, en düşük puan ise 33’tür.

Öğrencilerin görüşlerine dayanarak kazanımların elde edilmesinde şiirlerin etkisine ilişkin KŞET düzeyleri ortalamaları ve standart sapmaları yukarıdaki tabloda verilmiştir (Tablo 4). Buna göre en çok değişkenlik gösteren cevaplar Ko6 maddesine verilmiştir (ss=1,158). En az değişkenlik gösteren cevaplar K30 maddesine verilmiştir ( $\mathrm{ss}=0,873$ ). Ayrıca en yüksek ortalama 3,83 değeri ile K12 maddesine verilen cevaplara; en düşük ortalama ise 2,99 değeri ile $\mathrm{K} 17$ maddesine verilen cevaplara aittir (Tablo 5). Öğrencilerin, kazanımlarının elde edilmesinde şiirlerin etkisine ilişkin öğrenci görüşlerinin olumlu olduğu görülmüştür. Öğrenciler, şiirlerin T.C. İnkılâp Tarihi ve Atatürkçülük Dersi Öğretim Programı (2018) kazanımlarından en çok, "Çağdaşlaşan Türkiye'nin temeli olan Atatürk ilkelerini kavrar." kazanımının elde edilmesinde etkili olduğu yönünde görüş bildirmişlerdir.

\section{2. Öğrencilerin KŞET düzeylerinde cinsiyetlerine göre istatistiksel olarak anlaml bir fark var mıdır?}

Tablo 6. Cinsiyetlere göre KŞET düzeyleri ortalamalarına ilişkin t-testi tablosu

\begin{tabular}{lllllll}
\hline Cinsiyet & $\mathbf{N}$ & Ortalama & Standart Sapma & T & sd & $\mathbf{p}$ \\
\hline Kiz & 46 & 111,96 & 22,186 & 1,153 & 79 & 0,252 \\
Erkek & 35 & 105,46 & 28,546 & & & \\
\hline
\end{tabular}


Öğrencilerin KŞET düzeylerinde cinsiyetlerine göre istatistiksel olarak anlamlı bir farka rastlanmamıştır $(t(79)=1,153, p=0,252)$.

3. Öğrencilerin tarih ile ilgili derslere olan ilgi durumlarma göre KŞET düzeylerinde istatistiksel olarak anlamlı bir fark var midır?

Tablo 7. Tarih ile ilgili derslere olan ilgi düzeylerine göre KŞET düzeyleri ortalamalarına ait varyans analizi sonuçları

\begin{tabular}{|c|c|c|c|c|c|c|c|c|c|}
\hline $\begin{array}{l}\text { Tarih ile } \\
\text { ilgili } \\
\text { derslere } \\
\text { olan ilgi } \\
\text { düzeyi }\end{array}$ & $\mathbf{n}$ & Ortalama & $\begin{array}{l}\text { Standart } \\
\text { Sapma }\end{array}$ & $\begin{array}{l}\text { Varyansın } \\
\text { Kaynağı }\end{array}$ & $\begin{array}{l}\text { Kareler } \\
\text { Toplamı }\end{array}$ & sd & $\begin{array}{l}\text { Kareler } \\
\text { Ortalamas1 }\end{array}$ & $\mathbf{F}$ & $\mathbf{p}$ \\
\hline $\begin{array}{l}\text { Çok Zayıf } \\
\text { / Zayıf } \\
\end{array}$ & 11 & 104,82 & 24,899 & \multirow{2}{*}{$\begin{array}{l}\text { Gruplar } \\
\text { aras1 }\end{array}$} & \multirow{2}{*}{260,093} & \multirow[t]{2}{*}{2} & \multirow{2}{*}{130,046} & \multirow{3}{*}{0,201} & \multirow{3}{*}{0,818} \\
\hline Orta & 37 & 110,35 & 25,962 & & & & & & \\
\hline $\begin{array}{l}\text { Yüksek / } \\
\text { Çok }\end{array}$ & 33 & 109,24 & 24,983 & $\begin{array}{l}\text { Gruplar } \\
\text { içi }\end{array}$ & 50436,129 & 78 & 646,617 & & \\
\hline Toplam & 81 & 109,15 & 25,173 & Toplam & 50696,222 & 80 & & & \\
\hline
\end{tabular}

Tarih ile ilgili derslere olan ilgi düzeylerine göre KŞET düzeyleri ortalamalarında istatistiksel olarak anlamlı bir farka rastlanmamıştır $(\mathrm{F}(2,78)=0,201, \mathrm{p}=0,818)$.

4. Öğrencilerin şür okumayı sevme durumlarına göre KŞET düzeylerinde istatistiksel olarak anlaml bir fark var midır?

Tablo 8. Şiir okumayı sevme durumlarına göre KŞET düzeyleri ortalamalarına ait varyans analizi sonuçları

\begin{tabular}{|c|c|c|c|c|c|c|c|c|c|}
\hline $\begin{array}{l}\text { Şiir } \\
\text { Okumayı } \\
\text { Sevme } \\
\text { Durumların } \\
\text { a }\end{array}$ & $\mathbf{n}$ & $\begin{array}{l}\text { Ortalam } \\
\text { a }\end{array}$ & $\begin{array}{l}\text { Standar } \\
\text { t Sapma }\end{array}$ & $\begin{array}{l}\text { Varyansı } \\
\text { n Kaynağı }\end{array}$ & $\begin{array}{l}\text { Kareler } \\
\text { Toplamı }\end{array}$ & sd & $\begin{array}{l}\text { Kareler } \\
\text { Ortalamas } \\
\text { 1 }\end{array}$ & $\mathbf{F}$ & $\mathbf{p}$ \\
\hline Evet & 2 & 110,67 & 31,189 & Gruplar & & 2 & & \multirow{3}{*}{$\begin{array}{l}0,32 \\
6\end{array}$} & \multirow{3}{*}{$\begin{array}{l}0,72 \\
3\end{array}$} \\
\hline Hayır & 21 & 111,71 & 18,977 & arası & $4<<,<90$ & & 210,149 & & \\
\hline Kismen & 3 & 106,64 & 24,319 & Gruplar & 50275,925 & 78 & 644,563 & & \\
\hline Toplam & 81 & 109,15 & 25,173 & Toplam & $\begin{array}{l}50696,22 \\
2\end{array}$ & $\begin{array}{l}8 \\
0\end{array}$ & & & \\
\hline
\end{tabular}

Şiir okumayı sevme durumlarına göre KŞET düzeyleri ortalamalarında istatistiksel olarak anlamlı bir farka rastlanmamıştır $(\mathrm{F}(2,78)=0,326, \mathrm{p}=0,723)$.

5. Öğrencilerin şïr okuma durumlarına göre KŞET düzeylerinde istatistiksel olarak anlaml bir fark var midır? 
Tablo 9. Şiir okuma durumlarına göre KŞET düzeyleri ortalamalarına ait varyans analizi sonuçları

\begin{tabular}{|c|c|c|c|c|c|c|c|c|c|}
\hline $\begin{array}{l}\text { Şiir } \\
\text { Okuma } \\
\text { Durumu }\end{array}$ & $\mathbf{n}$ & Ortalama & $\begin{array}{l}\text { Standart } \\
\text { Sapma }\end{array}$ & $\begin{array}{l}\text { Varyansın } \\
\text { Kaynağı }\end{array}$ & $\begin{array}{l}\text { Kareler } \\
\text { Toplamı }\end{array}$ & sd & $\begin{array}{l}\text { Kareler } \\
\text { Ortalaması }\end{array}$ & $\mathbf{F}$ & $\mathbf{p}$ \\
\hline Hiçbir & 13 & 107,62 & 22,055 & \multirow{2}{*}{$\begin{array}{l}\text { Gruplar } \\
\text { arası }\end{array}$} & \multirow{2}{*}{1410,160} & \multirow{2}{*}{3} & \multirow{2}{*}{470,053} & \multirow{4}{*}{0,734} & \multirow{4}{*}{0,535} \\
\hline Nadiren & 33 & 106,67 & 21,965 & & & & & & \\
\hline Bazen & 23 & 108,43 & 30,973 & \multirow{2}{*}{ Grup içi } & \multirow{2}{*}{ 49286,062 } & \multirow{2}{*}{77} & \multirow{2}{*}{640,079} & & \\
\hline Sık Sık & 12 & 119,00 & 25,053 & & & & & & \\
\hline Toplam & 81 & 109,15 & 25,173 & Toplam & 50696,222 & 80 & & & \\
\hline
\end{tabular}

Şiir okuma durumlarına göre KŞET düzeyleri ortalamalarında istatistiksel olarak anlamlı bir farka rastlanmamıştır $(\mathrm{F}(3,77)=0,734, \mathrm{p}=0,535)$.

\section{Sonuç, tartışma ve öneriler}

Yapılan araştırma sonucunda, öğrencilerin ortaöğretim T.C. İnkılâp Tarihi ve Atatürkçülük dersi kazanımlarının elde edilmesinde şiirlerin etkisine ilişkin öğrenci görüşlerinin olumlu olduğu görülmüştür. Öğrenciler, şiirlerin T.C. İnkılâp Tarihi ve Atatürkçülük Dersi Öğretim Programı (2018) kazanımlarından en çok, "Çağdaşlaşan Türkiye'nin temeli olan Atatürk ilkelerini kavrar." kazanımının elde edilmesinde etkili olduğu yönünde görüş bildirmişlerdir. Benzer şekilde Çencen ve Akça Berk (2014)'in, Ortaöğretim T.C. İnkılâp Tarihi ve Atatürkçülük dersinde, şiir kullanımına ilişkin öğretmenlerin görüşlerini inceledikleri araştırmada, öğretmenlerin büyük bir çoğunluğunun T.C. İnkılâp Tarihi ve Atatürkçülük dersinde şiir kullanımının yararlılığına yönelik görüş bildirdikleri görülmüştür. Şengül Bircan ve Arıdil (2015)'in ilköğretim Sosyal Bilgiler derslerinde yer alan tarih konularının işlenişinde öğrencilerin şiir kullanımıyla ilgili görüşlerini aldıkları araştırmada da, öğrencilerin, ilköğretim Sosyal Bilgiler dersinde yer alan tarih konularının işlenişinde edebi bir ürün olarak şiir kullanımına yönelik görüşlerinin olumlu olduğu tespit edilmiştir. Öğrencilerin, Sosyal Bilgiler dersinde şiir kullanımının yararlı olacağına ve derslerde bu tür etkinliklere daha fazla yer verilmesi gerektiğine yönelik yanıtlar verdikleri görülmüştür.

$\mathrm{Bu}$ araştırmadan elde edilen bir başka sonuç ise öğrencilerin, ortaöğretim T.C. İnkılâp Tarihi ve Atatürkçülük dersi kazanımlarının elde edilmesinde şiirlerin etkisine ilişkin öğrenci görüşlerinde cinsiyetlerine göre istatistiksel olarak anlamlı bir fark bulunamamasıdır. Benzer şekilde Çencen ve Akça Berk'in (2014), ortaöğretim T.C. İnkılâp Tarihi ve Atatürkçülük dersinde, öğretmenlerin öğretim materyali olarak şiir kullanımına ilişkin görüşlerini aldığı araştırmada da öğretmenlerin şiir kullanımına yönelik düşüncelerinde cinsiyetlerine göre istatistiksel olarak anlamlı bir fark bulunamamıştır. Şengül Bircan ve Arıdil'in (2015), ilköğretim Sosyal Bilgiler derslerinde yer alan tarih konularının işlenişinde öğrencilerin şiir kullanımıyla ilgili görüşlerini aldıkları araştırmada, verdikleri 15 önermeden 3'ü hariç, öğrencilerin şiir kullanımına yönelik düşüncelerinde cinsiyetlerine göre istatistiksel olarak anlamlı bir fark bulunamamıştır.

Ortaöğretim T.C. İnkılâp Tarihi ve Atatürkçülük dersi kazanımlarının elde edilmesinde şiirlerin etkisine ilişkin öğrenci görüşlerinin "tarih ile ilgili derslere olan ilgi durumları"na, "şiir okumayı sevme durumları"na ve "şiir okuma durumları"na göre anlamlı bir fark olmadı̆̆ı tespit edilmiştir.

\begin{tabular}{r|l} 
Adres & Address \\
RumeliDE Dil ve Edebiyat Araştırmaları Dergisi & RumeliDE Journal of Language and Literature Studies \\
Osmanağa Mahallesi, Mürver Çiçeği Sokak, No:14/8 & Osmanağa Mahallesi, Mürver Çiçeği Sokak, No:14/8 \\
Kadıköy - İSTANBUL / TÜRKIYE 34714 & Kadıöy - ISTANBUL / TURKEY 34714 \\
e-posta: editor@rumelide.com & e-mail: editor@rumelide.com, \\
phone: +90 505 7958124, +90 2167730616
\end{tabular}


Bu çalışmada ortaöğretim T.C. İnkılâp Tarihi ve Atatürkçülük dersi kazanımlarının elde edilmesinde şiirlerin etkisine ilişkin öğrenci görüşleri tespit edilmeye çalışılmıştır. Çalışma sonuçlarından hareketle aşağıda yer alan önerilerde bulunulmuştur:

- Ortaöğretim T.C. İnkllâp Tarihi ve Atatürkçülük dersi kazanımlarının elde edilmesinde şiirler kullanılmalıdır.

- Yakar ve Ylldırım (2021)'ın ortaöğretim tarih ders kitaplarında edebî ürünlerin kullanımına yönelik yaptıkları çalışmada ortaöğretim tarih ders kitaplarında, edebî ürünlere sınıf düzeyine ve konuların özelliklerine göre yeterli oranda yer verilmediği görülmüştür. Ortaöğretim T.C. İnkılap Tarihi ve Atatürkçülük ders kitabında ise en az atasözü $(\% 1,1)$ ve şiir $(\% 1,1)$ türlerine yer verildiği sonucuna ulaşılmıştır. İlgili araştırmadan da anlaşıldığı üzere ortaöğretim sınıf T.C. İnkılap Tarihi ve Atatürkçülük ders kitabında en az yer verilen edebî türlerden biri de olmasına rağmen yaptığımız bu araştırmada ortaöğretim T.C. İnkılâp Tarihi ve Atatürkçülük dersi kazanımlarının elde edilmesinde şiirlerin etkisine ilişkin öğrenci görüşlerinin olumlu olduğu görülmüştür. Yapılan araştırmalarda da tarih konularının işlenişinde şiir kullanımıyla ilgili hem öğrenci görüşlerinin olumlu olması (Bircan ve Arıdil, 2015) hem de öğretmen görüşlerinin olumlu olması (Çencen ve Akça Berk, 2014) sebebiyle ortaöğretim T.C. İnkılâp Tarihi ve Atatürkçülük ders kitaplarında kazanımlara ilişkin şiirlere daha fazla yer verilmelidir.

- Ortaöğretim T.C. İnkılâp Tarihi ve Atatürkçülük dersi kazanımlarının elde edilmesinde şiirlerin etkisi hakkında tarih öğretmenleri bilinçlendirilmeli ve ortaöğretim T.C. İnkılâp Tarihi ve Atatürkçülük dersinde şiir kullanımından istenilen verimin alınabilmesi için tarih öğretmenlerine hizmetiçi eğitim verilmelidir.

\section{Kaynakça}

Büyüköztürk, Ş., Kılıç Çakmak, E., Akgün, Ö. E., Karadeniz, Ş. ve Demirel, F. (2010). Bilimsel Araştırma Yöntemleri. Ankara: Pegem Akademi.

Candan, A. S. (2003). Tarih öğretiminde ayrıntıl okuma becerilerinin geliştirilmesi. Doktora tezi. Gazi Üniversitesi Eğitim Bilimleri Enstitüsü, Ankara.

Certo, J. L. (2004). Cold plums and the old men in the water: Let children read and write "great" poetry. Reading Teacher, 58(3), 266-271. http://www.li.suu.edu/library/circulation/Marriott/eled346olmColdPlumsOldMenWaterFallo5 .pdf, (Erişim Tarihi: 12.04.2009).

Collins, P. (2008). Using poetry throughout the curriculum. Kappa Delta Pi Record, 44(2), 81-84. https://doi.org/10.1080/00228958.2008.10516500

Çencen, N. (2010). 11. sını Türkiye Cumhuriyeti İnklâp Tarihi ve Atatürkçülük dersinde tarih öğretmenlerinin "edeb̂̂ ürün" kullanımına ilişkin görüşleri. Doktora tezi. Gazi Üniversitesi Eğitim Bilimleri Enstitüsü, Ankara.

Çençen, N. ve Akça Berk, N. (2014). Ortaöğretim T. C. İnkılâp Tarihi ve Atatürkçülük dersinde "şiir kullanımına" ilişkin öğretmen görüssleri. Türk Tarih Eğitimi Dergisi, 3(1), 1-23.

Dunning, S. (1966). Why poetry?. The English Journal, 55(2), 158-161. http://www.jstor.org/stable/810613, (Erişim: 16.02.2018).

Harrison, D. L. \& Holderith, K. (2003). Using the power of poetry to teach language arts, social studies, math and more. New York: Scholastic.

Janeczko, P. B. (2003). Opening a door: Reading poetry in the middle school classroom. New York: Scholastic Professional Books.

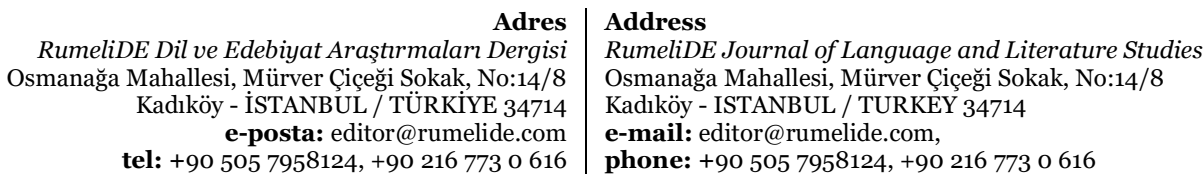


Karasar, N. (2012). Bilimsel araştırma yöntemi. Ankara: Nobel.

Kenworth, L. S. (1937). American history in verse. The Clearing House, 12(3), 169-171. http://www.jstor.org/stable/30174956, (Erişim Tarihi: 02.03.2018).

Kirman, J. (2007). Aesthetics in geography: Ideas for teaching geopraphy using poetry. Journal of Geography, 106(5), 207-214.

Köksal, H. (2010). Tarih öğretiminde epik şiirlerin kullanımı. M. Safran (Ed.), Tarih nasıl öğretilir? Tarih öğretmenleri için özel öğretim yöntemleri içinde (ss. 252-257). İstanbul: Yeni İnsan.

Liftig, I. F. (1993). Getting the point through poetry. Science Scope, 16(7), 22-24. http://www.jstor.org/stable/43177267, (Erişim Tarihi: 01.03.2018).

McCall, A. L. (2004). Using poetry in social studies classes to teach about cultural diversity and social justice. Social Studies, 95 (4), 172-176. https://doi.org/10.3200/TSSS.95·4.172-176

Milli Eğitim Bakanlığı (2018). Ortaöğretim T.C. İnkılâp Tarihi ve Atatürkçülük dersi öğretim programı. http://mufredat.meb.gov.tr, (Erişim Tarihi: 22.01.2018).

Osborne, K. (1987). Poetry and the teaching of Canadian history: The poems of F. R. Scott. History and Social Science Teacher, 22(3), 152-155.

Öztaş, S. (2009). Tarih öğretiminde şiirlerin yeri ve önemi. Uluslararası 5. Balkan Eğitim ve Bilim Kongresi "Günümüzde Balkanlarda Eğitim", Trakya Üniversitesi, 1-3 Ekim 2009, Edirne, Türkiye, C. 2, 294-298.

Öztaş, S. (2018). Tarih derslerinde bir öğretim materyali: Edebî ürünler. RumeliDE Dil ve Edebiyat Araştırmaları Dergisi, 11, 27-41.

Öztürk, C. ve Otluoğlu, R. (2005). Sosyal bilgiler öğretiminde edebî ürünler ve yazıl materyaller. Ankara: Pegem Akademi.

Stiles, L. J. (1965). What shall we do about poetry in the schools? The Elementary School Journal, 65(4), 175-178. http://www.jstor.org/stable/999139, (Erişim Tarihi: 16.02.2018).

Şengül Bircan, T. ve Arıdil, Ş. (2015). İlköğretim sosyal bilgiler dersinde bir edebi ürün olarak "şiir" kullanımına ilişkin öğrenci görüşlerinin değerlendirilmesi. M. Şahingöz (Ed.), Kaşgarlı’nın tarihçi torunu Reşat Genç armağamı içinde (ss. 361-371). Ankara: Türk Kültürünü Araştırma Enstitüsü.

Ulusoy, K. ve Gülüm, K. (2009). Sosyal bilgiler dersinde tarih ve coğrafya konuları işlenirken öğretmenlerin materyal kullanma durumları. Ahi Evran Üniversitesi Eğitim Fakültesi Dergisi, $10(2), 85-99$.

Vardell, S. M. (2006). Poetry aloud here!: Sharing poetry with children in the library. Chicago: American Library Association.

Walders, D. (2000). Poetry and science education. ERIC Digest. ED 463946. http://www.ericdigests.org/2003-1/poetry.htm, (Erişim: 16.02.2018).

Wilson, C. ve Kahn, B. B. (2008). Using poetry to teach the holocaust: Rationale and strategies for the middle level learner, North Carolina Middle School Association Journal, 23(1). http://www.ncmsa.net/journal/PDF/Febo8/Using-poetry.pdf, (Erişim Tarihi: 04.12.2009).

Yakar, H. ve Yıldırım, T. (2021). Ortaöğretim tarih ders kitaplarında edebî ürünlerin kullanımı. Ahi Evran Üniversitesi Sosyal Bilimler Enstitüsü Dergisi, 7(2), 409-426.

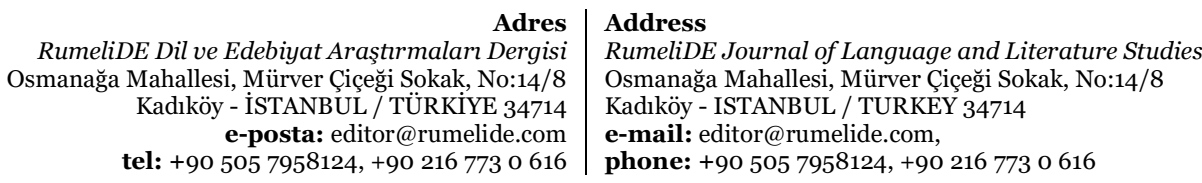

